\title{
DISEMINASI PERATURAN DESA (PERDES) UNTUK PENCEGAHAN KEBAKARAN LAHAN GAMBUT
}

\author{
Zulkarnaini dan Hasim As'ari \\ FISIP Universitas Riau, Kampus Bina Widya Km. 12,5 Simpang Baru Panam, Pekanbaru 28293
}

\begin{abstract}
Villagers living around peatlands utilize and manage peatlands based on their unwise practices, for example clearing land by burning for later planting. As a result, especially in the dry season, peatland fires are inevitable. The purpose of this paper is to focus on the need for initiation from local communities in peatland management in order to prevent fire outbreaks. The locus of research in villages prone to peatland fires on the coast of Bengkalis Regency, specifically Bandar Laksamana District. This study is in line with the Republic of Indonesia's Peatland Restoration Agency (BRG) program which prioritizes community participation in peatland management, especially rural communities located in the target areas of restoration. For this reason, BRG is currently promoting the Peat Cares Village program as a form of raising and strengthening community participation. One of the activities that is part of the Peat Cares Village is facilitating the government and village communities to develop regulations that can be used to support peat restoration in their village areas, especially related to fire prevention aspects. Although there are already formal rules at the national level regarding the management and protection of peatlands, their implementation has yet to reach the grassroots level. It is necessary to design local rules that depart from the values of wisdom and the spirit of self-help owned by the community in order to protect their environment from the adverse effects of fire events that often occur on peatlands. Because it comes from their initiatives and agreements, of course the rules will be more binding, so the application will be more leverage. Village regulations (Perdes) are one aspect that is very likely to be applied.
\end{abstract}

\begin{abstract}
Abstrak: Masyarakat desa yang tinggal sekitar lahan gambut memanfaatkan dan mengelola lahan gambut berdasarkan kebiasaan mereka yang kurang bijak, misalnya membuka lahan dengan cara membakar untuk kemudian ditanami. Sebagai akibatnya, terutama pada musim kering, kebakaran lahan gambut tidak bisa terhindarkan. Tujuan penulisan ini memfokuskan perlunya inisiasi dari masyarakat lokal dalam pengelolaan lahan gambut agar dapat mencegah terjadinya kabakaran. Lokus penelitian di desa-desa rawan terjadi kebakaran lahan gambut di pesisir Kabupaten Bengkalis, tepatnya Kecamatan Bandar Laksamana. Kajian ini sejalan dengan program Badan Restori Gambut (BRG) Republik Indonesia yang mengutamakan partisipasi masyarakat dalam pengelolaan lahan gambut, terutama masyarakat desa yang berada di wilayah target restorasi. Untuk hal itu BRG saat ini sedang menggalakkan program Desa Peduli Gambut sebagai salah satu bentuk penggalangan dan penguatan partisipasi masyarakat. Salah satu kegiatan yang menjadi bagian dari Desa Peduli Gambut adalah memfasilitasi pemerintah dan masyarakat desa untuk menyusun peraturan yang dapat digunakan untuk mendukung restorasi gambut di wilayah desanya terutama terkait dengan aspek pencegahan kebakaran. Meskipun sudah ada aturan formal di lingkup nasional tentang pengelolaan dan perlindungan lahan gambut, namun implementasinya masih belum menyentuh masyarakat di tingkat bawah. Perlu kiranya dirancang aturan lokal yang berangkat dari nilai-nilai kearifan dan semangat swadaya yang dimiliki masyarakat demi menjaga lingkungannya dari dampak buruk akibat peristiwa kabakaran yang sering terjadi di lahan gambut. Karena berasal dari inisiatif dan kesepakatan mereka, tentunya aturan tersebut akan lebih mengikat, sehingga penerapannya akan lebih maksimal. Peraturan Desa (Perdes) adalah satu aspek sangat dimungkinkan diterapkan.
\end{abstract}

Kata kunci: pencegahan kebakaran, lahan gambut, peraturan desa, diseminasi

\section{PENDAHULUAN}

Masyarakat yang hidup di sekitar lahan gambut terutama kawasan Provinsi Riau, pada umumnya memiliki standar perekonomian yang terbatas. Mereka memiliki persediaan modal yang relatif rendah, baik dalam bentuk hasil produksi, barang, ataupun uang. Pendidikan mereka juga di bawah rata-rata penduduk di ibukota kecamatan, karena lokasinya jauh dari pusat pendidikan dan tidak adanya dukungan dana untuk melanjutkan sekolah. Semua ini terjadi karena minimnya pengetahuan mereka tentang fungsi dan peran lahan gambut bagi kehidupan manusia.

Atas keterbatasan yang demikian, masyarakat memanfaatkan dan mengelola lahan gambut berdasarkan kebiasaan mereka yang kurang bijak, misalnya membuka lahan dengan 
cara membakar untuk kemudian ditanami. Akibatnya sudah bisa ditebak, peristiwa kebakaran masih akan kembali terjadi, begitu yang terjadi terus menerus. Menurut data Titik Api Aktif NASA pada platform Global Forest Watch Fires (2017), setengah dari peringatan titik api (hot spots) di Provinsi Riau terjadi di kawasan-kawasan yang dilindungi, termasuk kawasan Cagar Biosfer Giam Siak Kecil-Bukit Batu (GSK-BB).

Data lain menunjukkan sekitar 38 persen dari peringatan titik api di Provinsi Riau terdapat pada lokasi lahan gambut yang kaya akan stok karbon dan dapat melepaskan gas rumah kaca ke dalam atmosfer yang semakin memicu perubahan iklim global (Sutikno, et al, 2018). Kejadian kebakaran ini tidak hanya pada kawasan lahan milik perusahaan, namun juga terjadi di lahan-lahan perkebunan masyarakat. Kecamatan Bandar Laksmana Kabupaten Bengkalis merupakan wilayah yang berada dalam kawasan Cagar Biosfer GSK-BB. Qomar (2017) menyebutkan, bahwa Kecamatan Bandar Laksamana adalah lokasi yang paling sering mengalami peristiwa kebakaran lahan selama 12 tahun terakhir.

Pengelolaan lahan gambut yang tidak terkelola dengan baik memang sangat berdampak besar, tidak saja dari aspek ekologi, tapi lebih buruk lagi dari aspek ekonomi dan sosial masyarakat sekitar (Darmawan, 2015). Kesehatan masyarakat menjadi tumbal, terutama para warga lanjut usia, ibu hamil dan anak-anak yang menghirup udara beracun dari lahan yang terbakar. Ditambah lagi, selain peristiwa kebakaran, masyarakat setempat juga menghadapi banjir pada musim hujan. Air bah melanda akibat penggalian kanal-kanal gambut oleh perusahaan perkebunan dan kehutanan.

Kondisi lahan gambut di Cagar Biosfer GSK-BB khususnya Kecamatan Bandar Laksamana dan sekitarnya memang memprihatinkan, karena tanah dan airnya lebih banyak dikuasai oleh perusahaan perkebunan. Pengaturan air gambut ketika kemarau dan penghujan hanya dilakukan oleh perusahaan tanpa melibatkan masyarakat. Tidak ada koordinasi antara perusahaan dengan warga terkait dengan buka-tutup pintu kanal, sehingga masyarakat hanya jadi korban ketika kebakaran dan banjir (Arlinus, 2018). Nihilnya solusi dari korporasi dan pemerintah daerah tentunya membuat warga desa semakin tertindas sebagai korban. Karena itu dirasa perlu inisiasi dari masyarakat lokal dalam pengelolaan lahan gambut, yang mencakup mulai dari manajemen tata air, pencegahan dan pengendalian kebakaran, dan perlindungan sumber daya alam.

Badan Restori Gambut (BRG) yang dibentuk sejak tahun 2016 menyadari akan pentingnya dukungan dan partisipasi masyarakat dalam pengelolaan lahan gambut ini, terutama masyarakat desa yang berada di wilayah target restorasi. Untuk itu BRG menggalakkan program Desa Peduli Gambut sebagai salah satu bentuk penggalangan dan penguatan partisipasi masyarakat. Salah satu kegiatan yang menjadi bagian dari Desa Peduli Gambut adalah memfasilitasi pemerintah dan masyarakat desa untuk menyusun peraturan yang dapat digunakan untuk mendukung restorasi gambut di wilayah desanya. Saat ini BRG telah menyusun pedoman untuk memberikan informasi ihwal prosedur dan materi muatan penting dalam peraturan tersebut. Pengembangan selanjutnya diserahkan kepada pemerintah dan masyarakat desa sesuai dengan kondisi dan permasalahan yang dihadapi (BRG, 2017).

Prakarsa dari BRG ini sudah ada yang mulai diterapkan, termasuk beberapa desa di Provinsi Riau. Sejauh dari informasi yang ditelusuri, terdapat satu desa di Kecamatan Bukit Batu, yakni Desa Pematang Duku yang sudah membuat Peraturan Desa (Perdes) tentang Pengelolaan Lahan Gambut. Perdes ini dibuat atas pendampingan dari LSM Kaliptra bersama Jaringan Kerja Penyelamat Hutan Riau (Jikalahari). Awalnya warga berdiskusi tentang pentingnya menyusun peraturan desa di rumah kepala desa setempat. Hasil diskusi tersebut dilanjutkan dalam forum diskusi yang lebih serius di balai desa dengan kehadiran seluruh elemen masyarakat (www.pantaugambut.id/29 Agustus 2018).

Beberapa waktu kemudian mereka berhasil menerbitkan Peraturan Desa Nomor 7 
tahun 2017 tentang Pengelolaan Tata Air, Pengendalian Karhutla serta Pemanfaatan dan Perlindungan Sumber Daya Alam. Menariknya dalam Bab VII pasal 9 diatur sanksi bagi individu yang aktivitasnya mengganggu tata air gambut dan tidak melindungi sumber daya alam sehingga menyebabkan kebakaran dan kerusakan ekologi serta hidrologi gambut. Sanksi tersebut berupa denda sebesar Rp 20 juta dan mengganti kerugian yang ditimbulkan akibat kelalaian tersebut secara kekeluargaan. Perdes ini juga menyebut sanksi pidana sesuai dengan perundang-undangan di tingkat nasional. Sementara bagi pihak perusahaan, sanksi jauh lebih berat yakni Rp 500 juta ditambah dengan nilai kerugian yang diakibatkannya. Bahkan pemerintah desa bisa mengusulkan pencabutan izin.

Menurut pengakuan pemerintah desa di atas, sudah ada dampak positif sejak Perdes diberlakukan. Misalnya pada tahun 2014 dan 2015 atau sebelum Perdes dikeluarkan, kebakaran lahan gambut di desa cukup banyak dan sering terjadi. Namun setelah mereka belajar tentang penyebab kebakaran dari pengeringan gambut dan peraturan mulai diterapkan, banyak kemajuan yang diperoleh masyarakat. Tidak ada lagi kebakaran hutan dan lahan terutama di sekitar sekat kanal dan embung dibangun. Kalaupun ada kebakaran dengan cepat berhasil dicegah, sehingga api tidak sempat meluas. Hanya saja sosialisasi peraturan desa tersebut masih terbatas diberlakukan di kalangan masyarakat, sementara perusahaan di sekitar desa belum bisa terjangkau oleh Perdes.

\section{METODE}

Penelitian ini merupakan jenis pendekatan kualitatif dengan teknik penarikan sampel yang digunakan adalah snowball sampling. Informan penelitian adalah aparat yang terlibat dalam program pemberdayaan masyarakat di lokasi penelitian. Pengumpulan data dilakukan dengan tehnik wawancara dan observasi, setelah data terkumpul kemudian dianalisa dengan menggunakan analisa deskriptif kualitatif. Untuk tercapaian tujuan yang diharapkan, maka dilakukan langkah-langkah: Pertama, mengidentifikasi dan memahami tentang kondisi-kondisi yang ada (das sein). Berupaya mengidentifikasi dan memahami tentang kondisi-kondisi yang ada pada lokasi pengabdian tersebut secara keseluruhan. Aturan dan pedoman komponen-komponen dan faktor-faktor yang sesuai dengan model, serta menganalisa pola pemberdayaan masyarakat di ekosistem rawa gambut. Kedua, Mengidentifikasi tentang kondisi yang diinginkan (das dollen). Berisi berbagai faktor yang mungkin perlu perubahan dan perkembangannya dengan catatan perubahan yang diinginkan itu disesuaikan dengan kebutuhan masyarakat dan kondisi yang diinginkan harus keadaan yang mungkin dapat dicapai.

\section{HASIL DAN PEMBAHASAN Dinamika Pengelolaan Lahan Gambut}

Berdasarkan luas daerah, Kecamatan Bandar Laksamana bisa dikategorikan sebagai salah satu wilayah pengembangan dalam sektor pertanian dan industri di Kabupaten Bengkalis. Hal ini dapat dilihat dari luas wilayah dan mata pencaharian penduduk sehari-hari secara umumnya sebagai petani, nelayan, pedagang dan sebagian kecil bergerak di bidang jasa. Dilihat pada angka persentase perbandingan tingkat mata pencaharian, pada umumnya mata pencaharian masyarakat di sektor pertanian mencapai $55 \%$ dari jumlah keseluruhan penduduk 16.464 jiwa.

Terbukanya jalur-jalur transportasi dan komunikasi yang merupakan urat nadi perekonomian yang menghubungkan Kecamatan Bandar Laksamana khususnya Sungai Pakning dengan berbagai kota lainnya seperti Pekanbaru, Dumai, Selat Panjang, Batam dan Selat Malaka menyebabkan mobilitas masyarakat semakin meningkat. Dengan demikian terjadi berbagai transaksi ekonomi yang pada akhirnya akan meningkatnya kesejahteraan masyarakat dengan jalan meningkat berbagai hasil produksi pertanian maupun industri. Sebagai badan penggerak usaha-usaha tersebut saat ini telah berdiri beberapa lembaga ekonomi yang menunjang aktifitas perekonomian diantaranya Badan Usaha Milik Desa (BUMDES), kope- 
rasi umum, bank, pasar dan Perusahaan swasta lainnya. Beberapa perusahaan perkebunan dan industri sekarang ini sudah mulai melakukan aktifitasnya untuk dapat beroperasi. Dengan ini diharapkan iklim ekonomi akan semakin meningkat terutama dalam menyediakan lapangan kerja baru.

Dijadikannya sektor pertanian sebagai komoditas unggulan merupakan sesuatu yang wajar, karena wilayah Kecamatan Bandar Laksamana memiliki lahan yang luas. Apalagi sejak tahun 1990-an lahan-lahan yang tersedia, yang umumnya berjenis gambut sudah mulai digarap penduduk setempat. Menurut sejarahnya, pembukaan lahan gambut di daerah ini oleh masyarakat secara massif dilakukan mulai tahun 1992 dengan komoditas utama yang ditanam adalah karet (Arifudin, 2018). Awalnya dibuka oleh Perusahaan Hutan Tanaman Industri (HTI), kemudian berlanjut oleh masyarakat untuk ikut mengolahnya. Namun setelah masyarakat memiliki lahan tersebut, lahan yang diperoleh itupun akhirnya dijual ke orang lain yang pada umumnya tidak berdomisili di wilayah tersebut.

Pada tahap berikutnya perkebunan karet masyarakat berkembang dengan baik dan menjadi sumber perekonomian utama dalam pemenuhan kebutuhan hidup. Namun eksistensi perkebunan karet mulai tergerus setelah harga karet petani mengalami fluktuasi, bahkan cenderung turun dari tahun ke tahun. Harga karet yang terus anjlok membuat masyarakat harus mencari jalan lain untuk tetap bertahan dalam memenuhi kebutuhan hidupnya. Fenomena ini kemudian menjadi salah satu penyebab masyarakat mengkonversi perkebunan karet menjadi perkebunan kelapa sawit.

Perlahan-lahan kelapa sawit menjadi primadona yang diminati oleh masyarakat yang latah untuk menanam sawit. Masalahnya adalah lahan yang ditanami sawit merupakan lahan gambut yang cukup dalam sehingga masalah baru pun muncul dan menjadi momok bagi masyarakat. Lahan gambut yang telah ditanami sawit mengalami kekeringan dan sangat mudah terbakar. Pasca kebakaran, beberapa warga tidak lagi menggarap lahan mereka dan masih terbiarkan menjadi lahan-lahan tidur sampai saat ini. Lahan tidur inilah yang kemudian sering terbakar pada musim kering.

\section{Proses Pembuatan Perdes untuk Pencegahan Kebakaran di Lahan Gambut}

Sumber daya alam di lahan gambut hingga saat ini masih menjadi modal dasar pertumbuhan ekonomi yang sangat penting masyarakat di Kecamatan Bandar Laksamana. Namun dalam pengelolaannya kurang mengindahkan kaidah-kaidah pembangunan berkelanjutan, yang akhirnya berdampak pada kerugian ekonomi masyarakat itu sendiri. Salah satu bentuk pengelolaan sumber daya lahan gambut yang kurang terperhatikan adalah pola pikir jangka pendek, cepat, dan murah, yaitu pada saat penyiapan areal untuk budidaya dengan cara membakar.

Penyiapan areal melalui pembakaran telah berlangsung lama dan telah menjadi salah satu kearifan masyarakat lokal. Akibatnya, ketika jumlah penduduk yang semakin banyak, kondisi lahan yang rusak, ataupun kondisi iklim saat terjadi El Nino, pembakaran yang dilakukan pada periode yang sama menyebabkan kejadian kebakaran lahan dengan intensitas yang cukup tinggi. Hal ini terjadi pada belasan tahun terakhir dan pada tahun 2014-2016, kebakaran lahan di daerah ini berlangsung secara masif dalam jangka waktu cukup lama dan luasan yang besar. Akibatnya kerugian besar diderita oleh masyarakat, baik dalam aspek lingkungan dan sosial maupun ekonomi, serta mengarah pada trauma berkepanjangan.

Trauma warga desa yang tinggal di kawasan lahan gambut di Kecamatan Bandar Laksamana terhadap kebakaran hutan dan gambut pada tahun 2014-2016 mendorong mereka untuk melakukan tindakan antisipasitif. Desa-desa yang ada di kecamatan ini merupakan sebagian kecil dari puluhan desa di pesisir utara Riau yang lahan gambutnya terbakar. Akibatnya hampir setiap hari warga kedua desa terpaksa menghirup kabut asap beracun. Kesehatan masyarakat menjadi tumbal, terutama para warga lanjut usia, ibu hamil dan anak-anak. Tidak hanya itu, kebakaran hutan 
dan lahan gambut juga menghanguskan segi ekonomi, sosial dan lebih buruk lagi ekologi, karena letak desa berdekatan dengan Suaka Margasatwa Giam Siak Kecil yang merupakan hamparan gambut.

Tak ingin terjebak dalam bencana yang sama, masyarakat pun belajar tentang karakteristik gambut yang sudah rusak, kering, dan akhirnya mudah terbakar. Pengelolaan lahan gambut dan hutan memang menuntut kebijaksanaan. Selain kebakaran hutan, selama ini masyarakat setempat juga menghadapi banjir pada musim hujan. Air bah melanda akibat penggalian kanal-kanal gambut oleh perusahaan perkebunan dan kehutanan seperti Hutan Tanaman Industri (HTI). Pengaturan air gambut ketika kemarau dan penghujan juga hanya dilakukan oleh perusahaan. Tidak ada koordinasi antara perusahaan dengan warga terkait dengan buka-tutup pintu kanal. Sehingga masyarakat hanya jadi korban ketika kebakaran dan banjir.

Nihilnya solusi dari korporasi membuat warga desa bergerak bersama mencari pemecahan masalah. Dengan didampingi oleh LSM, warga berdiskusi untuk menyusun peraturan desa di rumah kepala desa setempat. Dari diskusi santai tersebut dilanjutkan dalam forum diskusi yang lebih serius di balai desa dengan kehadiran seluruh elemen masyarakat. Dalam pembahasan, warga menyadari bahwa desa mereka sangat rentan terhadap bencana kebakaran pada musim kemarau, dan banjir di musim hujan. Selain itu, terungkap pula bahwa muara kanal gambut yang dibuat oleh perusahaan di tepi laut dipenuhi limbah kayu perusahaan.

Meskipun sudah ada aturan formal di lingkup nasional tentang pengelolaan dan perlindungan lahan gambut, namun implementasinya masih belum menyentuh masyarakat di tingkat bawah. Maka terpikirkan untuk perlu kiranya dirancang aturan lokal (peraturan desa) yang berangkat dari nilai-nilai kearifan dan semangat swadaya yang dimiliki masyarakat demi menjaga lingkungannya dari dampak buruk akibat peristiwa kabakaran yang sering terjadi di lahan gambut. Proses perancangan
Perdes pun dimulai dengan mengikuti alur seperti gambar di bawah ini.

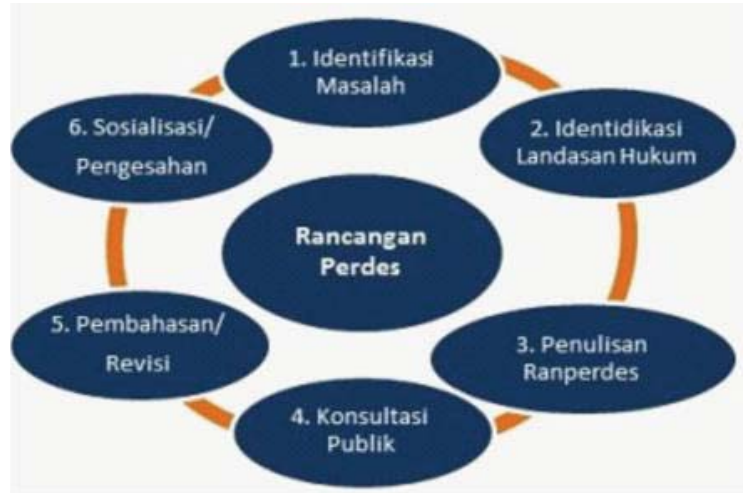

Gambar 1. Proses Pembuatan Rancangan Perdes

Pencegahan Kebakaran Lahan Gambut

Selanjutnya dari beberapa kali diskusi, disepakatilah untuk membuat peraturan desa yang mengatur tentang keberadaan Masyarakat Peduli Api (MPA) serta pengelolaan tata air, pengendalian karhutla, dan perlindungan sumber daya alam. Isi dari peraturan ini penekanannya pada sanksi bagi pihak yang melakukan tindakan kerusakan. Misalnya dalam Bab VII pasal 9 diatur sanksi bagi individu yang aktivitasnya mengganggu tata air gambut dan tidak melindungi sumber daya alam sehingga menyebabkan kebakaran dan kerusakan ekologi serta hidrologi gambut. Sanksi tersebut berupa denda sebesar Rp 20 juta dan mengganti kerugian yang ditimbulkan akibat kelalaian tersebut secara kekeluargaan.

Perdes juga menyebut sanksi pidana sesuai dengan perundang-undangan. Sementara bagi pihak perusahaan, sanksi jauh lebih berat yakni Rp 500 juta ditambah dengan nilai kerugian yang diakibatkannya. Bahkan pemerintah desa bisa mengusulkan pencabutan izin bagi perusahaan-perusahaan yang tidak mengindahkan aturan yang telah disepakati dalam Perdes.

\section{Pentingnya Diseminasi Perdes Pencegahan Kebakaran di Lahan Gambut}

Setelah Perdes berhasil dibuat, banyak kemajuan yang diperoleh masyarakat. Tahuntahun berikutnya tidak ada kebakaran hutan dan lahan terutama di sekitar sekat kanal dan embung air yang kita bangun. Pada awal tahun 
2019 sempat ada kebakaran, tapi karena ada embung api tidak sempat meluas. Selain menerbitkan Perdes, warga desa juga telah membangun sedikitnya enam embung dan tujuh sekat kanal. Diakui oleh salah seorang kepala desa, yakni H. Atim, Kepala Desa Tanjung Leban, bahwa perdes dan pembangunan embung serta sekat kanal cukup efektif menghadang kebakaran hutan.

Sayangnya sosialisasi peraturan desa tersebut belum diketahui seluruh masyarakat apalagi perusahaan yang ada disekitar desa. Padahal perusahaan di sekitarnya juga perlu dijangkau, karena pengeringan gambut terjadi bukan saja akibat aktivitas pertanian masyarakat tetapi juga perusahaan yang skalanya bahkan lebih masif. Penyebabnya adalah sulitnya berkomunikasi dengan pihak perusahaan karena mereka menutup diri dari aparat desa.

Semestinya peraturan yang ada perlu diimbangi dengan sosialisasi dan penyadaran terus menerus di antara seluruh warga. Perubahan dan perkembangan teknologi informasi dan komunikasi yang cepat dan dinamika sosial dan politik akan mempengaruhi pilihan strategi komunikasi dan diseminasi informasi publik. Hal ini menjadi tantangan sekaligus catatan bagi pejabat publik dan humas pemerintah untuk menyesuaikan diri dengan perkembangan dan perubahan tersebut. Secara umum pola komunikasi di masa mendatang relatif tidak berubah. Komunikasi linier, sebagai basis, tetap digunakan. Namun proses atau pendekatan komunikasi transaksional (yang bersifat diskusi interaktif, kooperatif, egaliter, resiprokal) akan makin berkembang dan menjadi kebutuhan.

Salah satu informasi dalam pencegahan kebakaran adalah perlunya dibuat Papan Peringatan Bahaya Kebakaran (PPBK), sebuah papan yang menunjukkan informasi potensi kebakaran pada lahan-lahan yang ada di desa. Di PPBK ini ada empat peringkat bahaya kebakaran yang ditunjukkan dengan warna yang berbeda, yaitu warna biru yang menunjukkan potensi kebakaran yang rendah, biru muda menunjukkan potensi sedang, kuning menunjukkan potensi yang tinggi, dan merah ber- arti sudah berbahaya.

Alasan penggunaan warna dan petunjuk sederhana ini adalah agar warga bisa mengerti secara mudah bagaimana keadaan dari lahan mereka setiap saat. PPBK ini sebetulnya bersifat pencegahan, yaitu agar masyarakat waspada terhadap kebakaran jika jarum penunjuk yang terbuat dari plastik berwarna abu-abu ini sudah berada pada posisi kuning. PPBK dijaga dan diperbaharui informasinya oleh staf pengurus desa dan Kelompok Masyarakat Peduli Api yang ditugaskan khusus untuk itu. PPBK harus diletakkan pada titik-titik strategis yang mencolok dan bisa dilihat oleh banyak orang.

Keberadaan Masyarakat Peduli Api (MPA) perlu juga diperhatikan ssecara lebih spesifik, karena mereka adalah kelompok masyarakat yang secara sukarela peduli terhadap pengendalian kebakaran hutan dan lahan. MPA harus dilatih dan diberi pembekalan serta dapat diberdayakan untuk kegiatankegiatan pengendalian kebakaran hutan. MPA ini tercantum dalam Peraturan Direktur Jenderal Perlindungan Hutan dan Konservasi Alam No P.2/IV-SET/2014. Biaya operasional, patroli, perawatan peralatan, dan kegiatan pemadaman MPA penting untuk disiapkan agar berkelanjutan. Salah satu alternatifnya adalah dengan mengembangkan usaha-usaha yang hasilnya secara khusus disisihkan untuk MPA.

\section{SIMPULAN}

Masyarakat yang hidup di lahan gambut Kecamatan Bandara Laksamana pada umumnya memiliki standar pemahaman yang terbatas. Dalam kondisi seperti itu, mereka memerlukan tambahan pengetahuan dan keterampilan melalui pelatihan dan pemberian pemahaman secara berkelanjutan, agar tidak salah dalam pemanfaatan lahan gambut. Termasuk pentingnya menanamkan pemahaman dalam mematuhi peraturan yang telah dibuat oleh pemerintah desa setempat tentang pencegahan kebakaran di lahan gambut. Hanya saja keberadaan Peraturan Desa (Perdes) ini kurang tersosialisasi atau tidak diketahui masya- 
rakat secara luas. Karena itu perlu dilakukan diseminasi Perdes yang ditujukan kepada kelompok target atau individu agar mereka memperoleh informasi tentang peraturan desa tentang pencegahan kebakaran lahan gambut, timbul kesadaran untuk menerima, dan akhirnya memanfaatkan informasi tersebut. Diseminasi Perdes ini merupakan suatu tindak inovasi yang disusun dan disebar berdasarkan sebuah perencanaan yang matang dengan pandangan jauh ke depan, baik melalui diskusi atau forum lainnya yang sengaja diprogramkan secara berkelanjutan.

\section{DAFTAR RUJUKAN}

Adinugroho, W. C., Suryadiputra, I. N. N., Saharjo, B. H., \& Siboro, L. 2005. Panduan Pengendalian Kebakaran Hutan dan Lahan Gambut. Bogor: Wetlands International - IP.

Agus, F., Anda, M., Jamil, A., \& Masganti. 2014. Lahan Gambut Indonesia: Pembentukan, Karakteristik, dan Potensi Mendukung Ketahanan Pangan. Jakarta: IAARD Press bekerjasama Badan Penelitian dan Pengembangan Pertanian Kementerian Pertanian RI.

Arifudin, Almasdi Syahza, Osamu Kozan, Kei Mizuno, Kosuke Mizuno, Zuli Laili Isnaini, Wahyu Iskandar, Sunawiruddin Hadi, Asnawi, Ayu Aizatul Natasya, Hasrullah, 2019. Dinamika Penggunaan, Kebakaran, dan Upaya Restorasi Lahan Gambut: Studi Kasus di Desa Tanjung Leban, Bengkalis, Unri Conference Series: Agriculture and Food Security 1: $40-45$

Arlinus, Zamzami. 2018. Peraturan di Dua Desa Ini Bisa Cegah Kebakaran Hutan. www.pantaugambut.id/29 Agustus 2018

Badan Restorasi Gambut. 2017. Pedoman Penyusunan Peraturan di Desa untuk Mendukung Restorasi Gambut. Jakarta: Kedeputian Edukasi, Sosialisasi, Partisipasi dan Kemitraan Badan Restorasi Gambut RI.

Darmawan, Budi. 2015. Rancang Bangun Model Pencegahan Kebakaran Ekosistem
Hutan Rawa Gambut. Pekanbaru: Pascasarjana Universitas Riau.

Darajati, Wahyuningsih. 2019. Grand Design

Pencegahan kebakaran hutan, kebun dan lahan 2017-2019. Jakarta: Kementerian Perencanaan Pembangunan Nasional/ BAPPENAS-Kementerian Lingkungan Hidup dan Kehutanan (KLHK)

Gaveau, D.L.A. et al. 2014. Major atmospheric emissions from peat fires in Southeast Asia during non -drought years: evidence from the 2013 Sumatran fires. Scientific Reports.

Huraerah, Abu. 2011. Pengorganisasi dan Pengembangan Masyarakat: Model dan Strategi Pembangunan Berbasis Kerakyatan. Bandung: Humaniora IKAPI.

Kementerian Lingkungan Hidup RI. 2012. Strategi Nasional Pengelolaan Lahan Gambut Berkelanjutan. Jakarta.

Noor, Muhammad. 2016. Debat Gambut; Ekonomi, Ekologi, Politik, dan Kebijakan. Yogyakarta: Gadjah Mada University Press.

Page, S. E.. 2016. The Ring of Fire: Tackling Indonesia's Peatland Fire Dynamic. Proceedings of the International Peat Congress, Kuching, Malaysia.

Pramana Y. 2012. "Bentuk dan Tingkat Partisipasi Stakeholder dalam Pengelolaan Cagar Biosfer Giam Siak Kecil-Bukit Batu Provinsi Riau”. Tesis. Bogor: Institut Pertanian Bogor. Qomar, Nurul. 2017. Kebijakan Pengelolaan Sumberdaya Cagar Biosfir Giam Siak Kecil-Bukit Batu Provinsi Riau. Bogor: Pascasarjana IPB.

Rohmah, Siti. 2014. "Model Pemberdayaan Ekonomi Perempuan Melalui Grassroot Microfinance Syariah. ”Jurnal SAWWA - Volume 10, Nomor 1.

Rushayati B, Sunkar A, Hermawan R, Masganti, Meliani R. 2014. "Model Public Private Partnership dalam Mengatasi Degredasi dan Deforestasi Hutan." Laporan Penelitian. Bogor: Fakultas Kehutanan IPB. 
Sujianto dan Zulkarnaini, 2017. Collaboratif Institutional Model, Pekanbaru: Alaf Riau.

Sutikno, Sigit, et al. 2017. Kajian Hidrologi Lanskap Giam Siak Kecil-Bukit Batu Kabupaten Bengkalis Provinsi Riau. Pekanbaru: UR Press.
Zulkarnaini dan Evawani Elysa Lubis, 2018. Pemberdayaan Masyarakat dalam Pemanfaatan Ekosistem Lahan Gambut. Jurnal Kebijakan Publik, Vol. 10, No. 2, Oktober. 